Eur. J. Mineral.

2009, 21, 163-175

Published online November 2008

\title{
Microbial weathering of Fe-rich phyllosilicates and formation of pyrite in the dolomite precipitating environment of a Miocene lacustrine system
}

\author{
MARÍA EsTHER SANZ-MONTERO ${ }^{1,2, *}$, JUAN PABLO RODRÍGUEZ-ARANDA ${ }^{1}$ and CECILIA PÉREZ-SOBA ${ }^{1,2}$ \\ ${ }^{1}$ Departamento de Petrología y Geoquímica, Facultad de Ciencias Geológicas, \\ Universidad Complutense, 28040 Madrid, Spain \\ *Corresponding author, e-mail: mesanz@geo.ucm.es \\ ${ }^{2}$ Instituto de Geología Económica, CSIC-UCM, C/ Antonio Novais 2, 28040 Madrid, Spain
}

\begin{abstract}
Sedimentary sequences composed of selenite gypsum, mudstone, and dolomite microbialites cropping out in the eastern part of the Madrid Basin were deposited in a mudflat - saline-lake system during the Miocene. In some dolomite beds enriched in detrital grains, dolomite crystals occur intergrown with framboidal pyrite clusters that in many cases are arranged along the associated phyllosilicate cleavages, which accounts for the mineral disaggregation, and eventually for the mineral replacement. Highresolution FE-SEM investigations across the interface between the pyrite and the phyllosilicate show that a single phyllosilicate is replaced by iron sulphides in different microsites, with retention of some aspects of the parent structure. Pyrite formed in the sediment as texturally complex framboids, coexisting with amorphous to poorly crystalline iron-rich sulphide phases, and include carbonaceous filaments with biogenic isotopic signatures $\left(\delta^{13} \mathrm{C}=-22.95 \%\right.$. Microprobe analytical data indicate the weathered phyllosilicates to be significantly depleted in Fe relative to $\mathrm{Si}$ and $\mathrm{Al}$. The selective release of $\mathrm{Fe}$ has not involved the mineral transformation to secondary phyllosilicates, which suggests a preferential microbial colonization of the Fe-bearing minerals rather than a thermodynamically driven degradation of those minerals. Depleted $\delta^{34} \mathrm{~S}$ values in pyrite further suggest that sulphate microbial reduction to sulphide was active within the sediment during the alteration of the silicates.

This paper gives new insight into the microbial weathering of phyllosilicates and the subsequent formation of pyrite through a sequence of intermediate products enriched in iron. These processes were coeval with the microbially-mediated precipitation of dolomite, which further reinforces the role of the microbes in the formation of the sulphides.
\end{abstract}

Key-words: bioweathering, Fe-bearing silicate, biomineralization, pyrite, saline-lakes.

\section{Introduction}

It is now accepted that since the early Precambrian the activity of microbes has had an impact on the evolution of the Earth's surface. Microbial activities promote both mineral formation and rock weathering generally by redox attack (Ehrlich, 1996, 1998).

Both igneous and sedimentary rocks are susceptible to microbial weathering, including siliceous (Ullman et al., 1996; Barker et al., 1997; Rogers \& Bennet, 2004; Wilson, 2004), carbonate and sulphate rocks (Sanz-Montero et al., 2006). The most basic mechanism by which all organisms affect mineral weathering reactions is by producing $\mathrm{CO}_{2}$. In addition, microbes also excrete organic acids and extracellular polymeric substances (EPS) that lead to mineral diagenesis or dissolution by several mechanisms (Barker \& Banfield, 1996; Barker et al., 1997; Ehrlich, 1998; Welch et al., 1999). Mineral composition also plays a role in the microbial weathering of silicates, since it has been suggested that microorganisms preferentially colonize those silicate surfaces that contain beneficial nutrients (Rogers et al., 1998; Roberts, 2004; Rogers \& Bennet, 2004). Iron is one of these essential nutrients which is often bound as a structural component of silicate minerals. Different studies have shown that metal-reducing bacteria are capable of reducing Fe (III) in silicate clays through complex transformations, with the variations in reductive rates depending upon medium composition (Kostka et al., 1999; Dong et al., 2003; Zhang et al., 2007). Along similar line, Kalinowski et al. (2000) and Liermann et al. (2000) showed that soil microbes accelerate the release of $\mathrm{Fe}$ from hornblende. Accordingly, Roden (2003) stated that Fe (III) minerals can represent long-term electron acceptors for organic matter oxidation, even where other respiratory processes are predicted to dominate.

Alternatively, the activity of the microbes contributes in many cases to the formation of different minerals. Specifically, bacterial sulphate reduction is the main mechanism involved in the production of pyrite at low temperatures in anoxic sediments (Trudinger et al., 1985; Machel, 2001). During bacterial sulphate reduction, the release of metabolic $\mathrm{CO}_{2}$ and the formation of bicarbonate ions lead to the precipitation of carbonates. The interrelationships between these processes allow the nearly coincident precipitation 


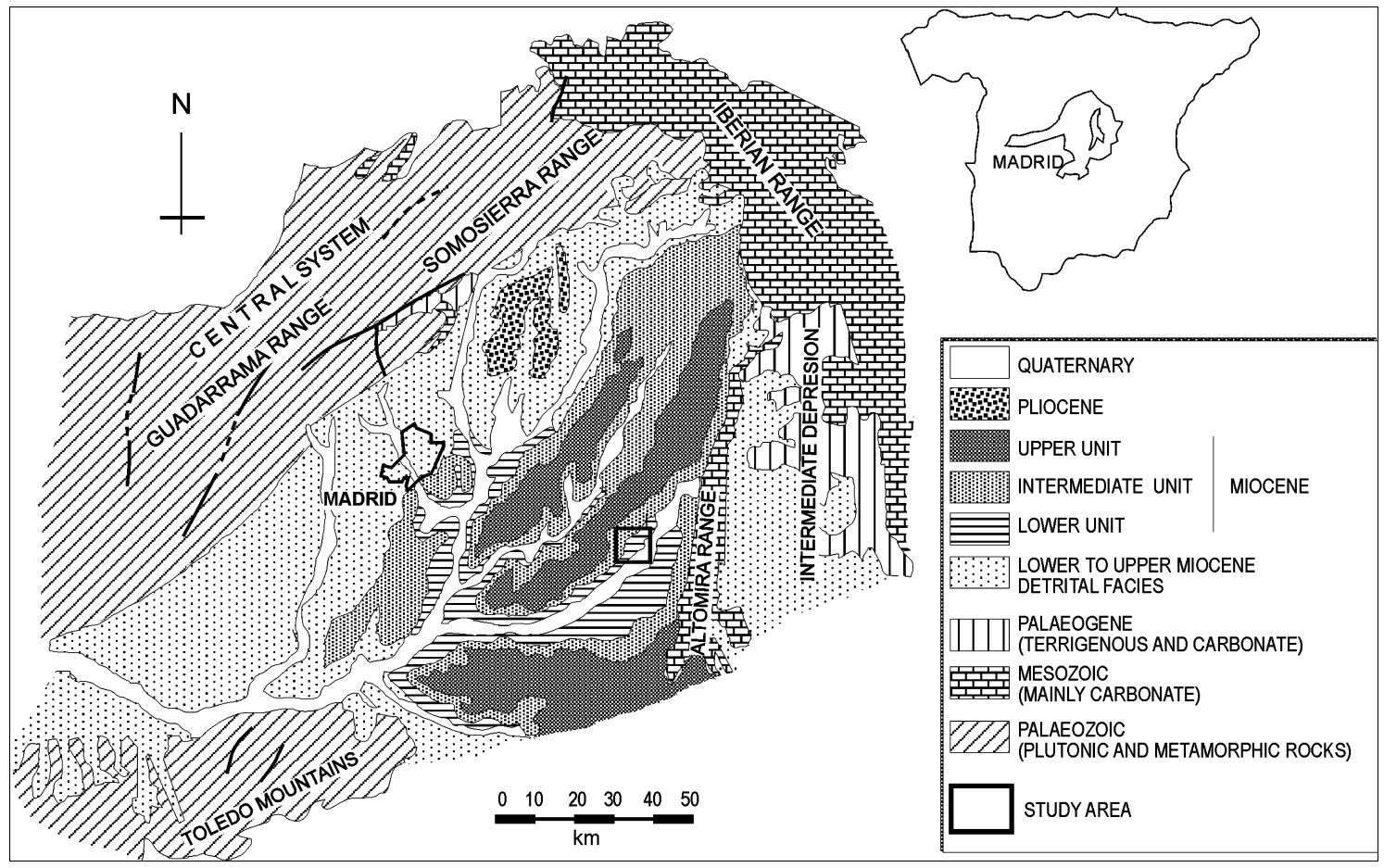

Fig. 1. Geological map of the Madrid Basin, in the centre of Spain, showing the position of the study area (squared).

of pyrite, carbonate, and even phosphate minerals (Glenn \& Arthur, 1988). Although calcite is considered to be the carbonate phase resulting from sulphate reduction processes (Machel, 2001), other studies on recent sediments from coastal areas have shown that sulphate reduction is the main mechanism involved in the formation of dolomite under Earth's surface conditions contributing significantly to the sedimentary carbonate budget (Vasconcelos \& McKenzie, 1997; Wright, 1999; Wright \& Wacey, 2005).

This paper reports a case of in situ phyllosilicate weathering caused by microbial activities, and the concomitant formation of pyrite. Together with these processes, coeval precipitation of dolomite took place in microbial mats that thrived in a Miocene saline-lake.

\section{Geological and sedimentary context}

The study beds are included in a 50-m thick evaporite formation referred to as a Christmas-tree gypsum unit (Rodríguez-Aranda et al., 1995), which crops out in the easternmost part of the Madrid Basin (Fig. 1). The Madrid depression is a Tertiary basin filled with more than $2000 \mathrm{~m}$ of terrestrial sediments (Calvo et al., 1996). The Miocene stratigraphic record of the basin is divided into three main lithostratigraphic units, each separated by unconformities from the underlying units. In many cases, palaeokarst occurs in relation to those unconformities (Rodríguez-Aranda et al., 2002). The ages of the three units are: Ramblian and early Aragonian, Aragonian to early Vallesian and Vallesian to Turolian, respectively. The Lower Unit, up to $900 \mathrm{~m}$ in thickness, consists mainly of halides, sulphates, carbonate, and mudstone deposits which were accumulated in hypersaline lakes (Ordóñez et al., 1991). The lake deposits interfinger with terrigenous deposits towards the margins according to a typical alluvial fan saline lake concentric pattern characteristic of closed basins (Eugster \& Hardie, 1978).

Gypsum and associated deposits forming the Christmastree gypsum unit are located at the top of the Lower Miocene Unit, and were accumulated in a peripheral lake isolated from the hypersaline lake spreading in the centre of the basin (Rodríguez-Aranda et al., 1995). The Christmas-tree gypsum unit comprises eight superimposed sedimentary sequences, basically formed of mudstone, marl, dolomite, and gypsum (Sanz-Montero et al., 2006).

The lower part of the each sequence generally consists of brown to green mudstone with gypsum nodules after anhydrite. It is interpreted as typical of a saline mudflat subenvironment (Sanz-Montero et al., 2006). The middle part of each sequence is composed of green mudstone and white to cream dolomite beds showing laminated fabric typical of stromatolites (Fig. 2). All the deposits show displacively grown gypsum nodules after anhydrite. The facies association recognized in the middle part of the sequence represents a transition from a saline mudflat to a lacustrine margin subenvironment. Sanz-Montero et al. (2006) have established a microbial origin for the formation of dolomite within cyanobacterial mats that covered the lake margins.

The upper part of the sequence comprises mainly grey gypsum and white to beige dolomite, with local overprints of anhydrite nodules. The gypsum is characterized by twinned selenite crystals in which the re-entrant angle systematically opens downward (Rodríguez-Aranda et al., 1995). 

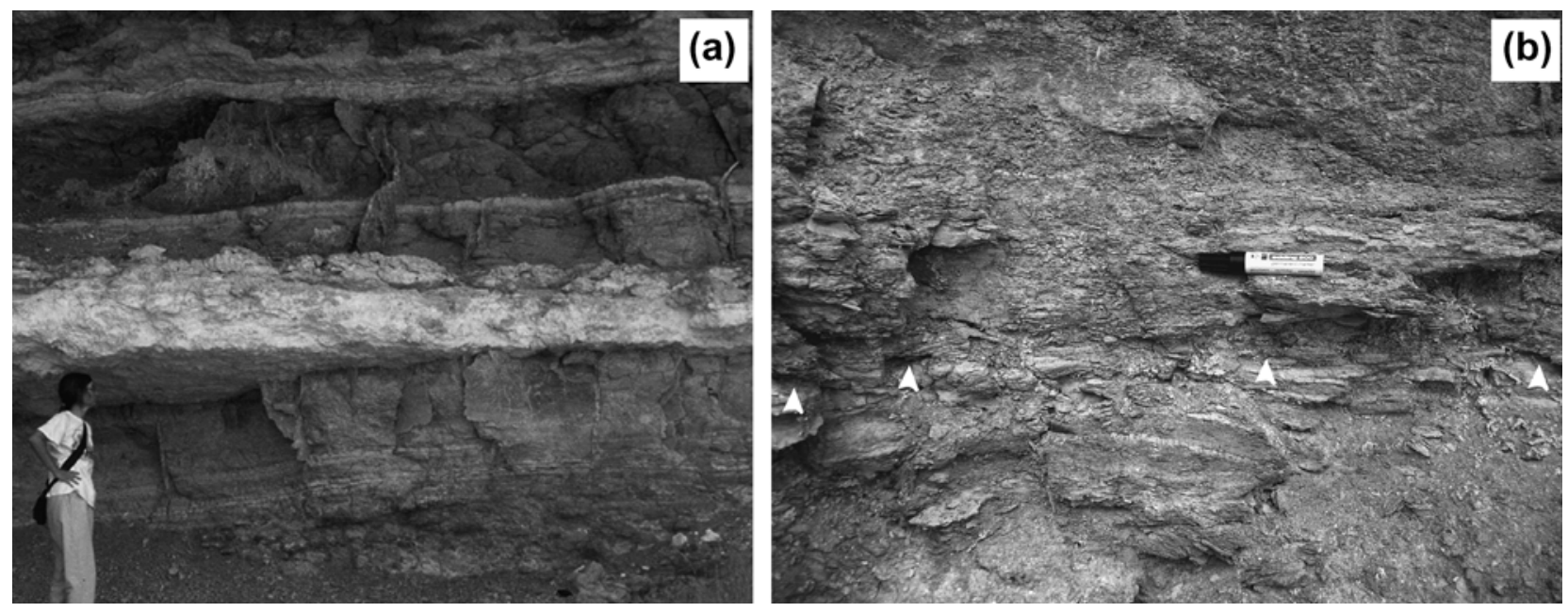

Fig. 2. Outcrop photographs of the middle part of the sedimentary sequence. (a) Green mudstone and white dolomite beds showing laminated and domal fabrics. (b) The basal facies association shown in (a) consists of cm-thick dolomite beds interbedded with pyritebearing laminae (arrowed).

The gypsum forms tabular $0.5-3 \mathrm{~m}$ thick beds overlaid by $\mathrm{cm}$-thick dolomite stromatolites. These deposits were accumulated in a saline lake, in which dolomite precipitated as a microbial product related to the development of microbial mats during relatively diluted stages (Sanz-Montero et al., 2006; Ayllón-Quevedo et al., 2007). In this setting, pervasive replacement of the sulphate by dolomite was caused by the activity of endolithic microorganisms, which produced extensive boring and corrosion of the gypsum crystals concomitantly with the precipitation of dolomite.

\section{Methods}

Eleven bulk samples from pyrite-bearing beds were analyzed by X-ray powder diffractometry (XRD). Five thin sections were examined using optical and fluorescence microscopy (Olympus BX51 equipped with a U-RFL-T).

Scanning electron microscope (SEM) studies were conducted on three polished thin sections and seven fresh broken surfaces using a JEOL JSM-6400 apparatus equipped with an energy-dispersive spectrometry device (EDS). To examine the compositional heterogeneities of the samples, backscattered electron imaging was used. High-resolution textural analyses of the mineral interfaces were carried out with field emission scanning electron microscopy (FE-SEM) (JEOL JSM-6335F). Forty-eight electron-microprobe (EMP) analyses of the silicate, carbonate, and pyrite minerals were carried out by wavelength dispersive mode, using a JEOL Superprobe JXA 8900-M equipped with four crystal spectrometers. Beam diameter was between $2-5 \mu \mathrm{m}$ to minimize damage from the electron beam. $\delta^{34} \mathrm{~S}$ analyses of two bulk samples containing pyrite were performed by Activation Laboratories (Canada). Whereas, $\delta^{34} \mathrm{~S}$ and $\delta^{18} \mathrm{O}$ measurements in six bulk samples of gypsum were performed by the Stable Isotope Laboratory of the University of Salamanca. Results for sulphur and oxygen are reported in the permil notation relative to the international CDT and SMOW standards, respectively. For stable-isotope analysis of carbonates, seven samples were ground to pass through a 100 mesh sieve; the 250 mesh fraction was saved for analysis. Carbon dioxide was evolved from each sample at $25{ }^{\circ} \mathrm{C}$ using $100 \% \mathrm{H}_{3} \mathrm{PO}_{4}$. The analytical precision is generally $0.10 \%$ for carbon and $0.15 \%$ for oxygen. Both oxygen and carbon values are reported in permil relative to Peedee belemnite standard (PDB). The analyses were also performed by the Stable Isotope Laboratory of the University of Salamanca. Total organic carbon (TOC) determinations in seven bulk samples and the carbon isotope composition of three of the samples enriched in $\mathrm{C}$ were carried out by the Stable Isotope Laboratories of the Royal Holloway University of London. The general analytical technique utilized has been described by Grassineau (2006). The samples were previously digested in $20 \%$ $\mathrm{HCl}$ for $12 \mathrm{~h}$ to remove any carbon from the carbonate. Carbon Isotope compositions were determined by measuring three separated fractions of the samples relative to high-purity, calibrated reference gas standards with a precision in the order of \pm 0.1 . The instrumentation used was a VG/Fisons/Micromass Isochrom-Elemental Analyzer system. Isotope ratios for carbon are expressed using the $\delta$ notation relative to PDB.

\section{Results}

\subsection{Petrography and composition of carbonates}

This study is concentrated in the middle part of the sequences in which dolomite stromatolite beds occur interdigitated with grey to green centimetre-thick laminae enriched in silt-sized detrital grains (Fig. 2b). Frequently, pyrite clusters concentrate in these laminae that contain empty pores and occasionally smell of $\mathrm{H}_{2} \mathrm{~S}$. The pores have diameters ranging from 10 to $250 \mu \mathrm{m}$ (Fig. 3) and probably resulted from pressure of gas trapped beneath sedimentsealing microbial mat layers as the grain distribution around 


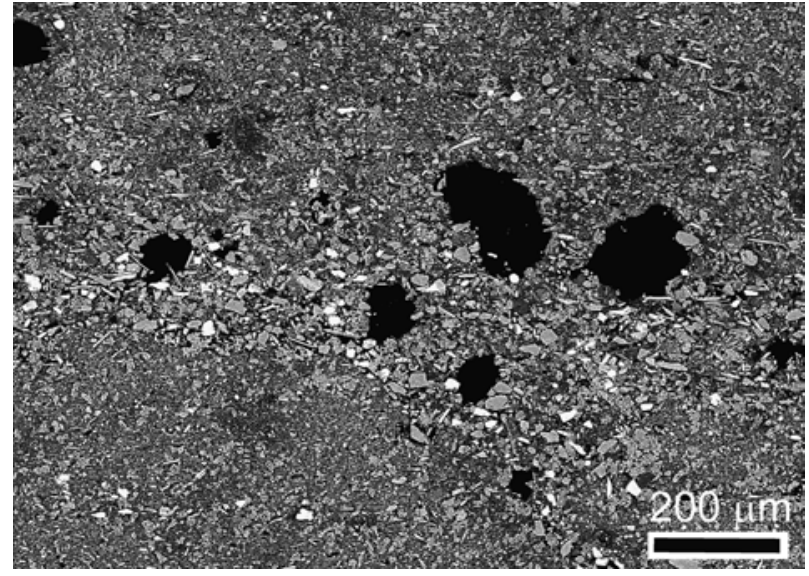

Fig. 3. SEM-BSE photograph of a thin section showing empty pores within a lamina enriched in silt-sized detrital grains. Pores are attributed to the escape of gases trapped beneath the detrital layers. Pyrite clusters (white grains) are concentrated in the closeness of the pores.

the pores suggests (Gerdes et al., 2000). The detrital grains are characterized as quartz, feldspars, and phyllosilicates (muscovite, biotite, chlorite, illite, and smectite). Carbonates are composed of dolomite and, subordinately, magnesite. The isotopic composition of the carbonate samples is characterized by negative values for carbon $\left(\delta^{13} \mathrm{C}_{\mathrm{PDB}}\right.$ ranging from -7.35 to $-5.08 \%$ ), with the less negative value corresponding to magnesite. Dolomite had negative $\delta^{18} \mathrm{O}_{\mathrm{PDB}}$ values (ranging from -3.76 to $-2.66 \%$ ), while magnesite yielded a positive $\delta^{18} \mathrm{O}_{\mathrm{PDB}}$ value $(2.57 \%$ ).

The carbonate beds comprise of bindstone showing shrub and clotted microfabrics (Fig. 4 and 5). Observations under fluorescence microscopy reveal the carbonate crystals all fluoresce (Fig. 4b). The fluorescence patterns and the distribution of $\mathrm{C}$ not bound in carbonates, obtained by digital mappings in some samples, show a notorious correlation indicating that some organic matter is associated with the crystals and it should be responsible for the luminescence of the carbonate. In addition, the TOC content in the pyrite bearing samples ranges from 0.37 to $0.94 \mathrm{wt} . \%$, whereas these values are lower by one order of magnitude (0.06-0.08 wt.\%) in the interbedded facies. The isotopic composition of the insoluble organic residue from the pyritic beds yielded $\delta^{13} \mathrm{C}_{\mathrm{PDB}}$ values between -19.56 and $-23.92 \%$, averaging $-22.95 \pm 0.15 \%$. Observations under SEM also evidence the intimate association of carbonaceous microfibrils along with other organic remains in the carbonate crystals (Fig. 4c and 5), attributable to fossil EPS (Sanz-Montero et al., 2006).

The shrub microfabrics consist of fan-shaped bundles of dolomite crystals radiating from a central surface that comprise a cylindrical empty pore. The up to $30 \mu \mathrm{m}$ wide and $25 \mu \mathrm{m}$ long carbonate bundles branch distally, exhibit morphological variability and do not repeat crystallographic patterns (Fig. 4a, b). In detail, dolomite and magnesite occur as micrite and microsparite crystals, in many cases made by the stacking of thin platelets and irregular bodies that may exhibit rhombohedral terminations (Fig. 4c). Magnesite typically is characterized by elongated dumbbell shaped crystals.
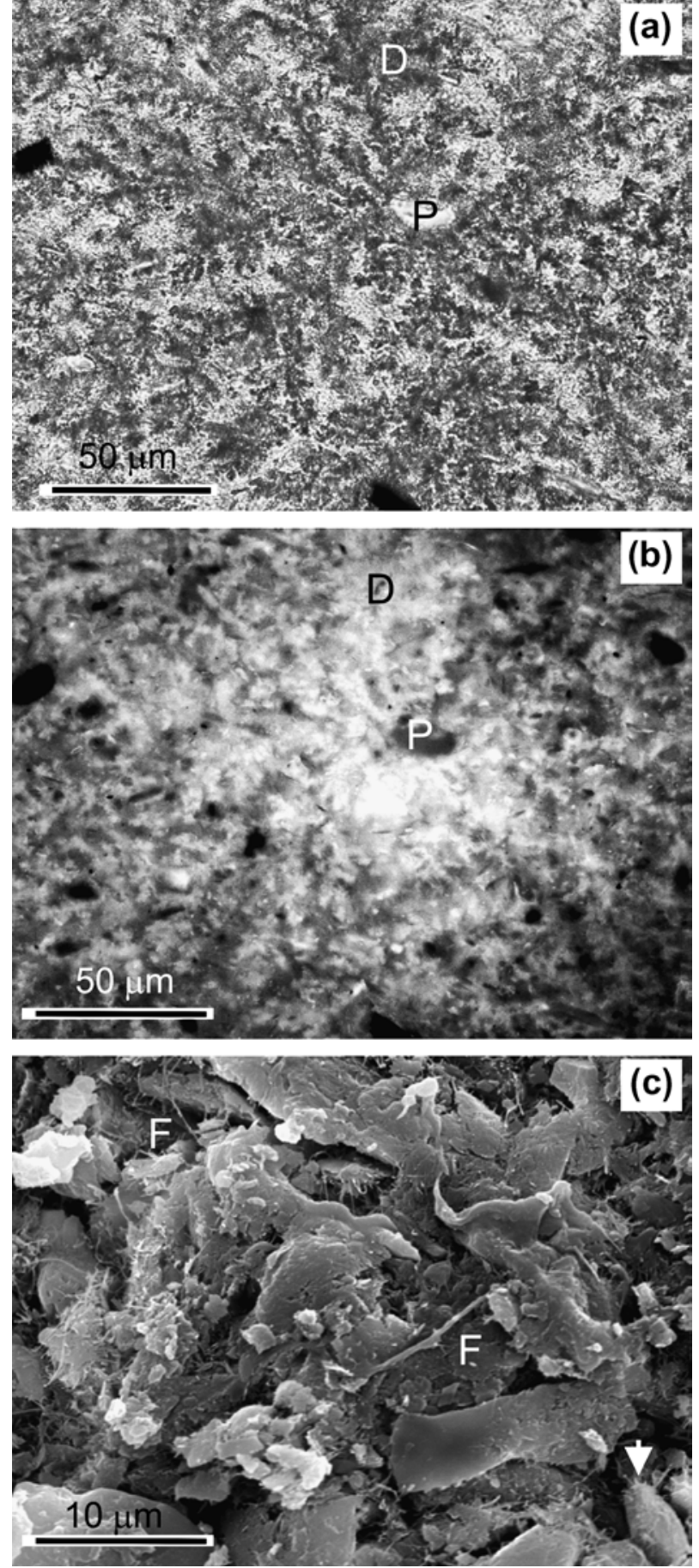

Fig. 4. Photographs showing the shrub microfabric of carbonate beds. (a) The shrubs consist of dolomite bundles (D) that radiate from a central pore $(\mathrm{P})$. Microphotograph under polarized plane light. (b) Epifluorescence image of (a). Note dolomite shrubs (D) all fluoresce, whereas the porosity $(\mathrm{P})$ and the trapped and bound sediment particles (mainly layered silicates) do not. (c) SEM image of a fan-shaped carbonate bundle spreading from a point in the lower left corner. The crystals results from the aggregation of thin platelets and enclose abundant EPS remains, mostly microfibrils (F). The white arrow indicates a dolomite crystal showing rice-grain morphology.

Dolomite shows more varied morphologies ranging from poorly crystallized forms to rice-grain textures that 

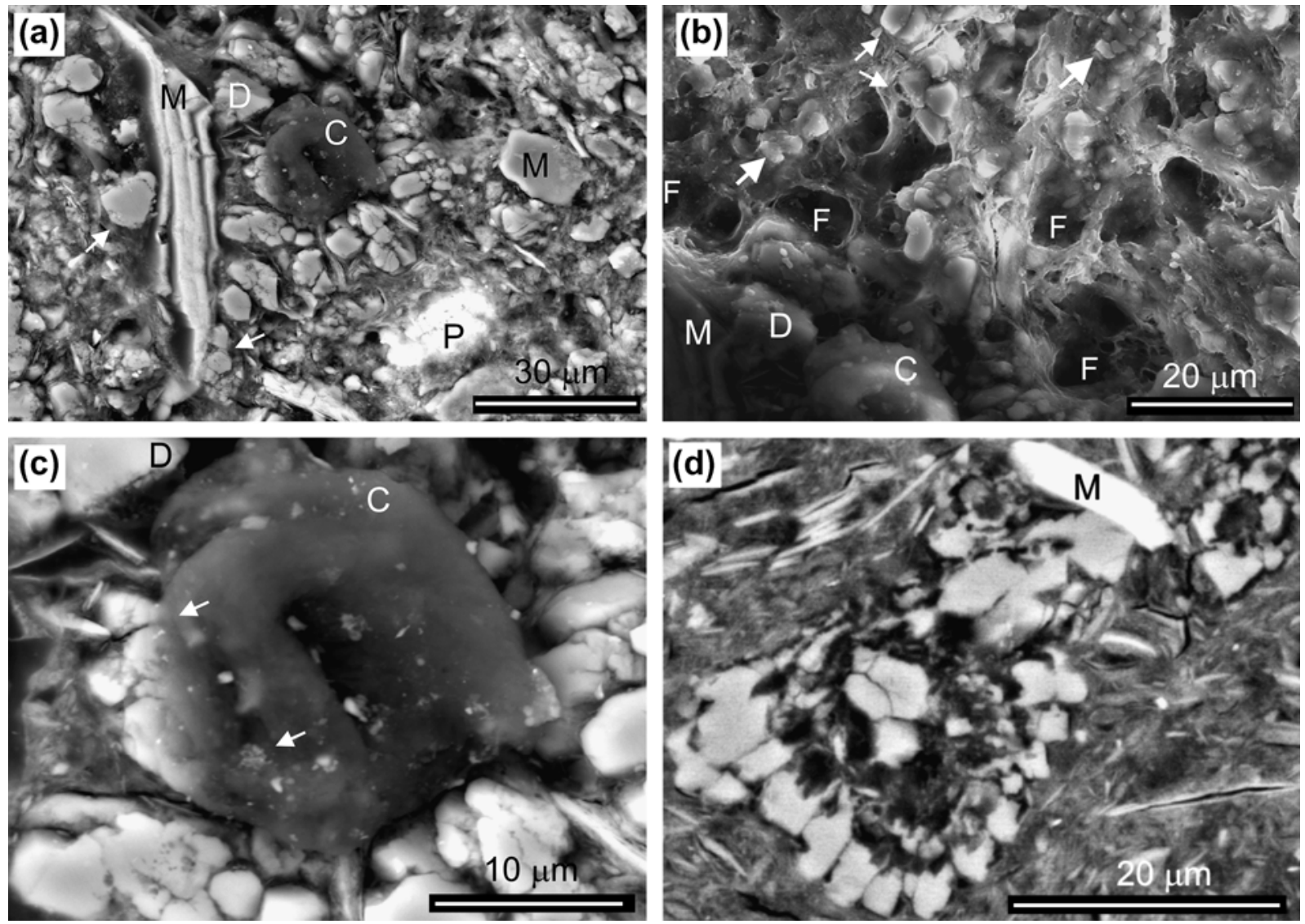

Fig. 5. SEM-BSE (a, c, and d) and SEM-SE (b) micrographs showing the intimate association of dolomite crystals (D) with carbonaceous substances $(\mathrm{C})$, silicate grains, mostly muscovite $(\mathrm{M})$ and pyrite $(\mathrm{P})$, in a detrital-bearing lamina. (a) General view of the laminae showing a pyrite framboid $(\mathrm{P})$ embedded in a veil of organic substances. (b) Poorly crystallized dolomite precipitates (arrowed) resting on organic templates with alveolar arrangements (F). (M), (C), and (D) are the same components shown in (a). (c) Magnified view of the carbonaceous substance shown in (a) surrounded and replaced by dolomite (white crystals). Arrows point to some dolomite crystals nucleated on it. (d) Clusters of dolomite crystals arranged around black carbonaceous cores displaying colonial arrays.

frequently occur associated with organic substances (Fig. 5). In some cases the carbonate precipitates are embedded in an alveolar network of EPS (Fig. 5b). In other cases, nanometresized dolomite crystals are nucleated on more disorganized organic masses (Fig. 5c). Likewise, dolomite often displays a characteristic texture of round-shaped crystals with carbonaceous cores, most between 5 and $25 \mu \mathrm{m}$ in size. Many of them coalesce forming concentric arrangements that frequently resemble colonial structures (Fig. 5d).

SEM-EDS and EMP analyses of the carbonates characterize the dolomite as slightly calcic and detect the presence of variable amounts of $\mathrm{Mn}(0.14-0.61$ wt.\%) and $\mathrm{Fe}(0.12-0.53$ wt.\%). These elements can be accompanied by significant proportions of $\mathrm{Si}$ and $\mathrm{Al}$. The crystals pervasively contain some $\mathrm{S}$, which is a common component of correlative microbial dolomites of adjacent basins (Sanz-Montero et al., 2008). Magnesite typically contains minor $\mathrm{Mn}$ and $\mathrm{Ca}$ and variable amounts of Si and Al.

\subsection{Petrography and composition of pyrite}

In the laminae containing detrital grains and empty pores, different proportions of carbonate crystals and framboidal pyrite mix together with the silicates (Fig. 3 and 6). Pyrite framboids occur isolated or, more frequently, grouped into clusters, which resemble the array of the dolomite crystals (Fig. 6). The framboids are systematically concentrated in the vicinity of the phyllosilicate surfaces, especially biotite (Fig. 6), whereas this sulphide is absent in muscovite and other close silicates. Frequently, the pyrite arranges along the cleavage surfaces of the phyllosilicates, causing its complete disaggregation (Fig. 6b, c). In some cases, the pyrite even replaces the phyllosilicates with a notorious preservation of the parent structure (Fig. 7). EDS analyses of the relicts also indicate that the replaced minerals were biotite. In addition, biotite may have undergone corrosion by densely packed dolomite crystals. By contrast, the surrounding dolomicrite matrix is characterized by loosely packed arrangements (Fig. 7). Thus, dolomite and pyrite crystals may be interlocked in the intergranular spaces and along the surfaces of the weathered phyllosilicates (Fig. 7 and 8a). The carbonate and pyrite crystals may have caused displacement in the sediment grains, which is consistent with a contemporary growth in an unconsolidated sediment. Other authigenic components that are interspersed in the groundmass include elemental sulphur, amorphous phosphate concretions, and tabular celestite crystals up to $15 \mu \mathrm{m}$ long. 

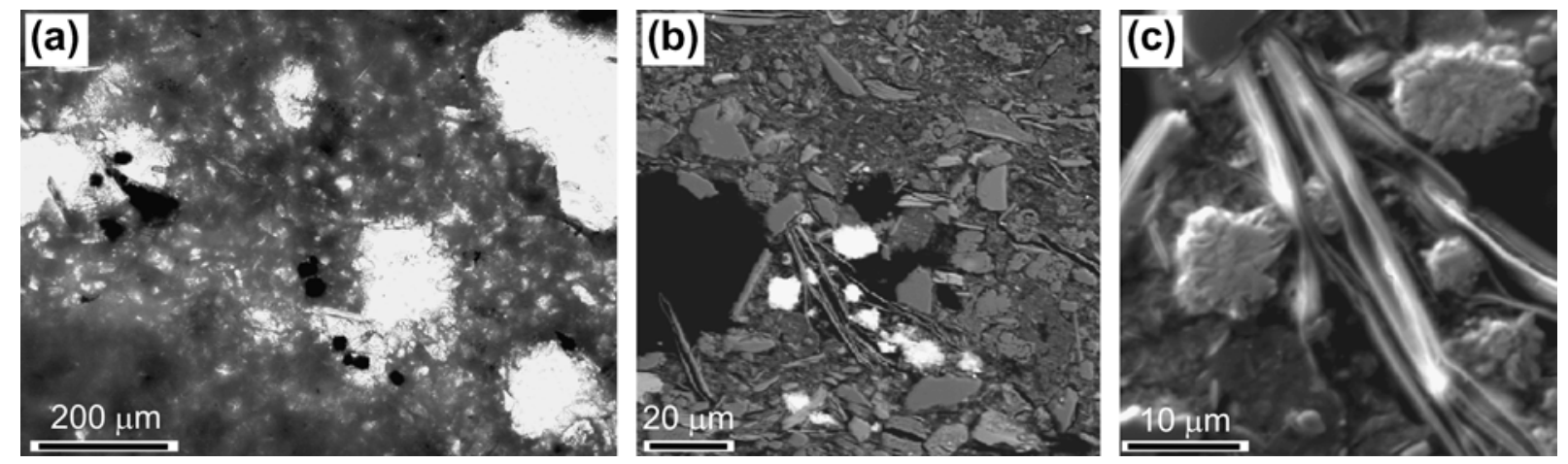

Fig. 6. Images showing close relationships between pyrite clusters and phyllosilicate grains. (a) Microphotograph under polarized plane light of a thin section of clotted dolomite enriched in silt-sized detrital grains (white spots) overlaying a purer dolomite lamina. Pyrite clusters (black minerals) are arranged along the layers of the Fe-phyllosilicates. Note the presence of pores in the closeness of the sulphides, ascribable to the escape of gases. (b) SEM-BSE magnified image of the pore on the left shown in (a). Detrital grains occur intermixed with dolomite clots. Pyrite aggregates (white minerals) are found in the layers of a biotite grain, causing its breaking. (c) SEM-SE photography showing a detail of (b). Pyrite crystals show pointed edges distorting the biotite.

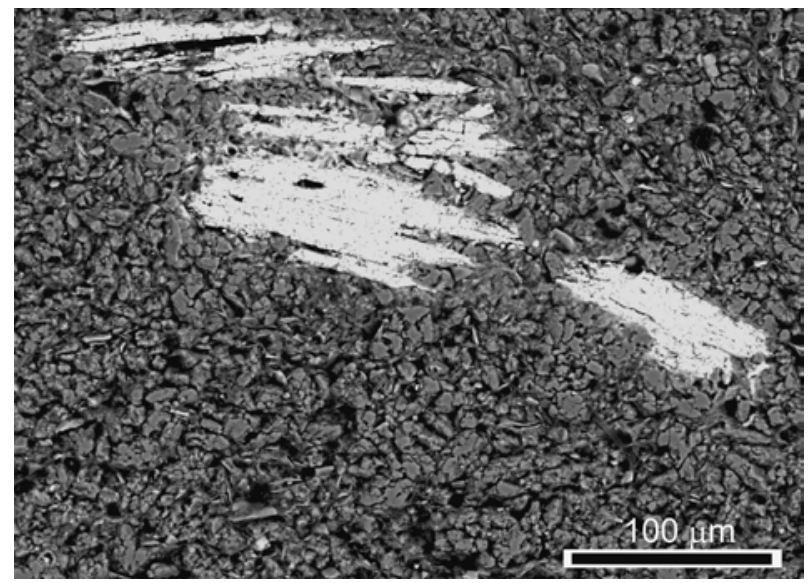

Fig. 7. SEM-BSE view of a pseudomorph of phyllosilicate replaced by pyrite. Simultaneously, dolomite crystals corrode the silicate. The microfabric of the dolomite associated with the phyllosilicate is markedly more compacted than that observed in the embedding dolomicrite. Notice that in the exploited planes of the silicate, dolomite, and sulphide occur intermixed, which denotes coevality.

In detail, pyrite framboids occurs as poorly crystallized forms up to $40 \mu \mathrm{m}$ in size, which are complex both compositional and texturally (Fig. 8 and 9). Pyrite crystals tend to be isometric although frequently display pointed edges that distort the phyllosilicates (Fig. 6c). These edges as well as the outer rim of the sulphide crystals are generally composed of poorly developed phases enriched in iron, which typically exhibit alveolar arrangements (Fig. 8). Clusters of these iron-rich phases can also occur aligned inside the layered silicates (Fig. 8a, b). Commonly, pyrite grains are embedded in organic membranes (Fig. 5a) that may form an alveolar network similar to the structure of EPS (Fig. 8c).

Figure 9 shows the complex microtexture that pyrite framboids often display. Inside the grossly defined framboid may coexist: massive spongy with irregular crack pattern areas, aggregates of iron-rich spheroidal to oblong crystallites, roughly cubic subcrystals, and pyritic moulds of filaments. In addition, carbonaceous filaments occur throughout and may even extend to the adjacent pyrite grains.

Eleven EMP analyses conducted on different pyrite grains indicate a wide range of variation in the $\mathrm{SO}_{3}$ content (wt.\%) from 6.98 to 44.97, and in the $\mathrm{FeO}$ content (wt.\%), oscillating from 36.19 to 62.23 . The higher values of $\mathrm{FeO}$ are observed in the poorly crystallized parts of the framboids. On the contrary, the $\mathrm{SO}_{3}$ content increases in the more idiomorphic crystallites. The analyses also detect variable amounts of $\mathrm{Si}, \mathrm{Al}, \mathrm{Mg}, \mathrm{Ca}, \mathrm{K}$, and $\mathrm{Ti}$ in the iron sulphide grains derived from the weathered phyllosilicates.

The pyrite $\left(\delta^{34} \mathrm{~S}_{\mathrm{CDT}}=-5.8 \%\right.$ and $\left.-39.4 \%\right)$ is significantly depleted in ${ }^{34} \mathrm{~S}$ relative to the associated gypsum with an average $\delta^{34} \mathrm{~S}_{\mathrm{CDT}}$ value of $17.7 \%$, standard deviation $=0.5 \%$.

\subsection{Composition of phyllosilicates}

According to EMP analyses conducted on the phyllosilicates associated with pyrite in the detrital bearing laminae, the phyllosilicate are mostly characterized as biotite, chlorite, muscovite (or illite), and smectite (Table 1, which is deposited and freely available on the EJM website at GeoScienceWorld, http://eurjmin.geoscienceworld.org/. Moreover, data indicate that the weathered phyllosilicates (greatly biotite) are significantly depleted in $\mathrm{Fe}$ relative to $\mathrm{Si}$ and $\mathrm{Al}$ (Fig. 10). Thus, the selective release of Fe has not involved the transformation of biotite to secondary phyllosilicates. Likewise, the values of $\mathrm{FeO}$ in biotite and chlorite are distinctly lower than those of the most abundant correlative minerals cropping out in granite and gneiss source areas reported by Pérez-Soba (1992), Villaseca \& Barbero (1994) and Villaseca \& Ubanell (2005). The estimated percentages of $\mathrm{FeO}$ (wt.\%) depletion may reach up to 24 in biotite and up to 40 in chlorite. In contrast, muscovite and smectite analyses do not yield anomalous results for this cation (Fig. 10). 

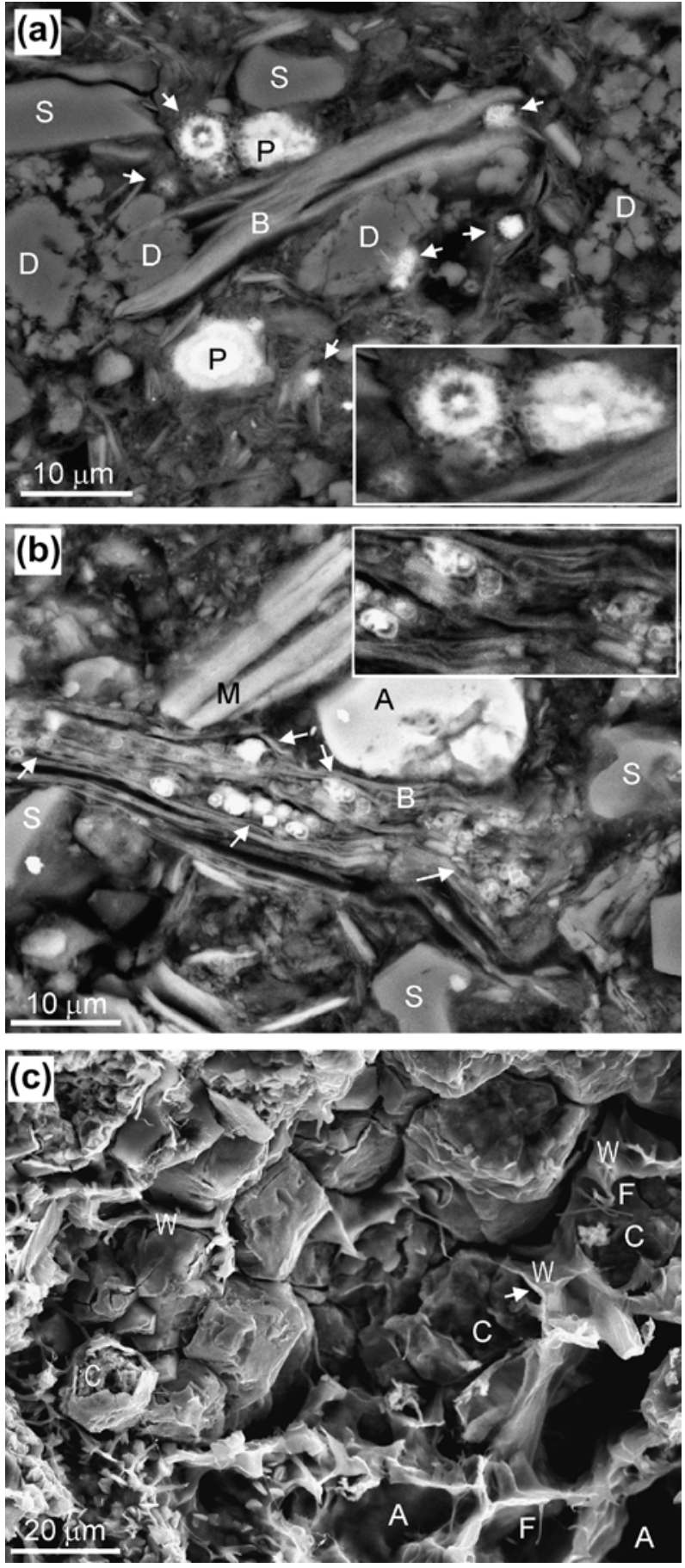

Fig. 8. SEM-SE photographs of a thin section $(\mathrm{a}-\mathrm{b})$ and a fresh broken sample (c). (a) Iron sulphides and dolomite crystals (D) precipitated both in the intergranular pore spaces of the silicate grains (S) and in the inner surfaces of an exfoliated biotite (B). Iron-rich sulphides (arrowed) are linked to pyrite grains (P) and exhibit an alveolar structure, magnified in the inset (width $16 \mu \mathrm{m}$ ). (b) Poorly developed crystals of iron-rich sulphides (arrowed) arranged inside a biotite (B). Adjacent detrital grains such as muscovite (M), apatite (A), and other silicate minerals (S) lack this type of alteration. The typical cocci morphologies of the iron-rich phases are magnified in the inset (width $20 \mu \mathrm{m}$ ). (c) Pyrite framboids embedded in an alveolar network of EPS (A) with abundant carbonaceous fibrils (F). The iron sulphides consist of a porous core (C) with numerous subcrystals enveloped by thin membranes $(\mathrm{W})$.

\subsection{The phyllosilicate-pyrite interface}

High magnification images of the phyllosilicate-pyrite interfaces evidence that the weathering front is unevenly distributed and it does not follow a defined pattern (Fig. 11). Pyrite grains typically show prolongations or points that are "rooted" in the distorted phyllosilicates (Fig. 6c and 11). These "roots" may replace the phyllosilicate, with a rough preservation of the parent structure (Fig. 11c). The qualitative SEM-EDS analyses of the different phases recognizable in the weathering front reveal a complex sequence of accumulation of $\mathrm{Fe}$ from the parent silicate (biotite) to the neoformed product (iron sulphide) passing through intermediate amorphous mixtures (Fig. 11 and 12). The iron accumulation is coupled with a gain of $\mathrm{S}$, and locally some $\mathrm{Mn}$, and a concomitant loss of $\mathrm{Si}, \mathrm{Al}, \mathrm{K}, \mathrm{Mg}$, and $\mathrm{Ti}$. Variable amounts of $\mathrm{C}$ are also detected throughout. Other mineral phases such as a Ca-rich phosphate are also recognizable in the inner surfaces of the exfoliated phyllosilicates and in the closeness of the interface between the phyllosilicate and the iron sulphide (Fig. 11c). Spheroidal bodies, $100-250 \mathrm{~nm}$ in size, abound in the sulphides. Although in less quantity, these bodies are also recognizable in the phyllosilicate surfaces subjected to weathering. Furthermore, the sulphide exhibits moulds a few microns in length that resemble bifurcated filaments (Fig. 11b).

In some laminae the phyllosilicates not only are exfoliated but also replaced by pyrite, which accounted for the preservation of the parent structure (Fig. 12). Texturally, the replacing sulphides consist of a porous mixture of pyrite crystallites and amorphous sulphides enriched in Fe. Pyrite crystallites, which are preferentially arranged along the exfoliation planes of the phyllosilicates, display a wide range of sizes and morphologies (Fig. 12c).

\section{Discussion and interpretation}

\subsection{Mineral precipitation in microbial mats}

Sanz-Montero et al. (2006) interpreted the carbonate beds from the study on gypsum formation as stromatolites arising from the lithification of microbial mats that thrived in the lake margins. The current paper supports this interpretation on the basis of observations on the middle part of the succession, specifically the precipitation of the carbonates in organic templates, strengthen this interpretation. The isotopic signature $\left(\delta^{13} \mathrm{C}=-22.95 \%\right)$ of the organic carbon (kerogen) preserved in these rocks is consistent with their biological origin (Konhauser, 2007). In addition, the magnesite in some beds shares textural properties with the microbial carbonates described by Vasconcelos \& McKenzie (1997), and Wright (1999) from modern coastal lakes. Similarly, the epifluorescence, branching and irregular morphologies observed in carbonate shrubs suggest that microbial communities were likely responsible for initiating carbonate growth (Chafetz \& Guidry, 1999; Fraiser \& Corsetti, 2003). Biogenic carbonate shrubs have been recognized only in environments containing $\mathrm{H}_{2} \mathrm{~S}$, perhaps because only 

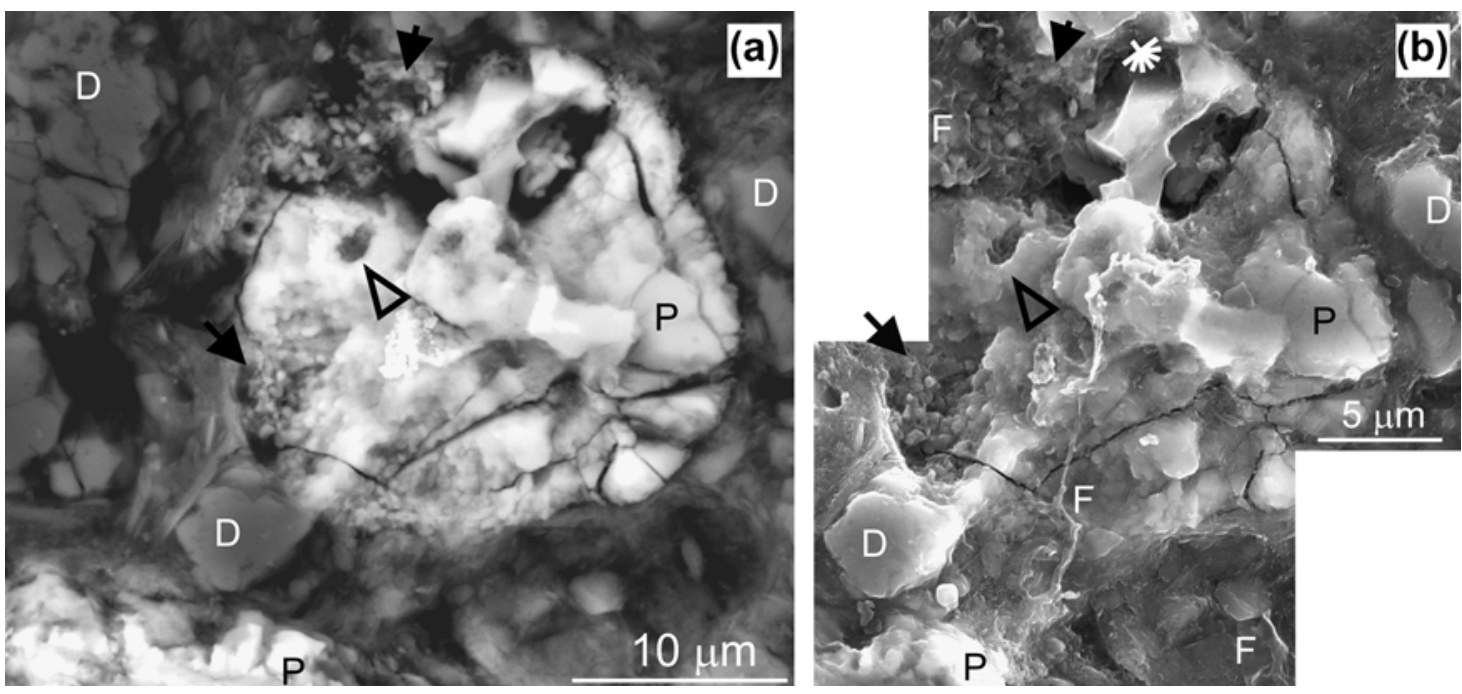

Fig. 9. SEM-BSE (a) and SE (b) images showing the textural and compositional complexity of pyrite aggregates (P), characterized by a framboid-like morphology. Framboids consist of a mixture of subcrystals that are assembled from smaller spheroids 10 's of nm in size (black arrows), through-shaped moulds of pyritic filaments (hollow arrow), massive with irregular cracking parts, and idiomorphic crystallites (white arrow head). Image (b) highlights the ubiquity of carbonaceous filaments (F) throughout the sulphide and spanning the distances between the adjacent crystals. Notice similar textures and gradual transitions from pyrite to dolomite (D) crystals.

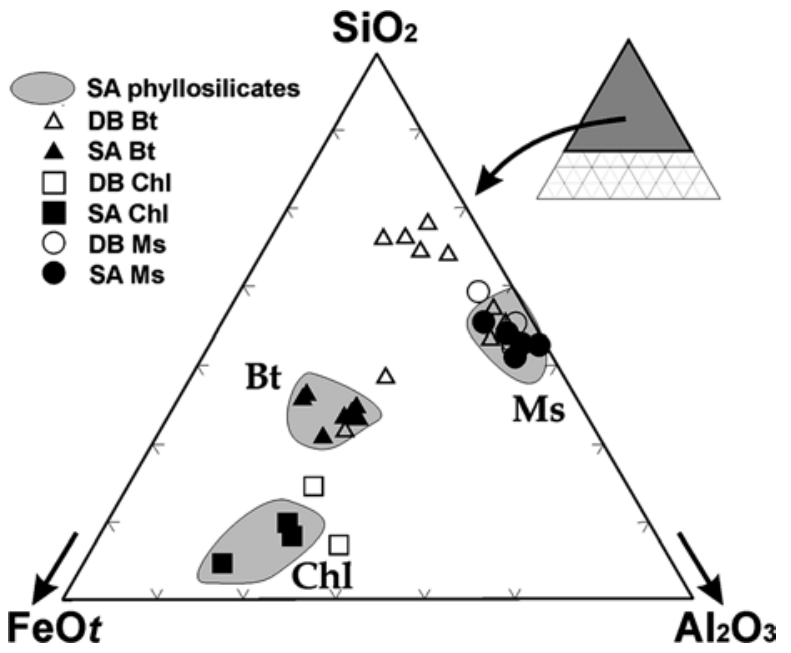

Fig. 10. Ternary plot of $\mathrm{SiO}_{2}-\mathrm{Al}_{2} \mathrm{O}_{3}-\mathrm{FeO}$ (as wt.\%) showing $\mathrm{FeO}$ depletion in the three main groups of phyllosilicates (Chlorite: Chl, Biotite: Bt, and Muscovite: Ms) deposited in the dolomite beds (DB) relative to representative phyllosilicates in the source areas (SA).

microbes can thrive in these environments (Chafetz \& Guidry, 1999). The Miocene carbonates are significantly enriched in ${ }^{12} \mathrm{C}$, which further supports the incorporation of organically derived carbonate ions in the minerals. In addition, depleted ${ }^{18} \mathrm{O}$ isotopic values in the dolomite exclude evaporation as a main formative process and indicate that the water from which they precipitated was relatively diluted (Sanz-Montero et al., 2006; Ayllón-Quevedo et al., 2007). By contrast, positive ${ }^{18} \mathrm{O}$ isotopic values in the magnesite suggest it formed in more concentrated waters.

\subsection{Microbial sulphate reduction}

In the Miocene sedimentary context, the alluvial-fans episodically supplied the mudflat-marginal lake areas with fine-grained detrital deposits burying the microbial mats developed on the lake bottom. The pressure of gas trapped beneath sediment-sealing microbial mat layers likely gave rise to the pores in the silty layers between the mat laminae (Fig. 3). Fenestral fabrics shown by the pores are typical phenomena of microbial mats that seal the sedimentary surfaces by their EPS (Gerdes et al., 2000). In that context, the degradation of the photosynthetically produced organic matter by sulphate reducing bacteria probably led to the precipitation of early diagenetic "mat-decaying mineralization" (Schieber, 1999). In modern microbial mats these processes lead to carbonate precipitation including dolomite and magnesite minerals (Vasconcelos et al., 2006). Early diagenetic pyrite formation also requires organic material decay by sulphate reduction to release dissolved sulphide. The presence of $\mathrm{H}_{2} \mathrm{~S}$ remains and depleted sulphur isotopic ratios in the Miocene pyrite support that sulphate bacterial reduction was operative during the sulphide formation. Pyrite and dolomite crystals coexist in the intergranular pore spaces and in the weathered surfaces of the phyllosilicates. In many cases, both minerals may have even caused displacement in the sediment grains, which is indicative of their early diagenetic precipitation within an unconsolidated sediment. The close textural interconnections between pyrite and dolomite in Miocene samples suggest a genetic tie between the minerals and point to the nearly coincident precipitation of the sulphide and the carbonate. This is consistent with the sulphide, metabolic $\mathrm{CO}_{2}$ and $\mathrm{P}$ release to pore water during bacterial sulphate reduction of organic matter (Glenn \& Arthur, 1988). Rasmussen (1996) also found coeval phosphates 

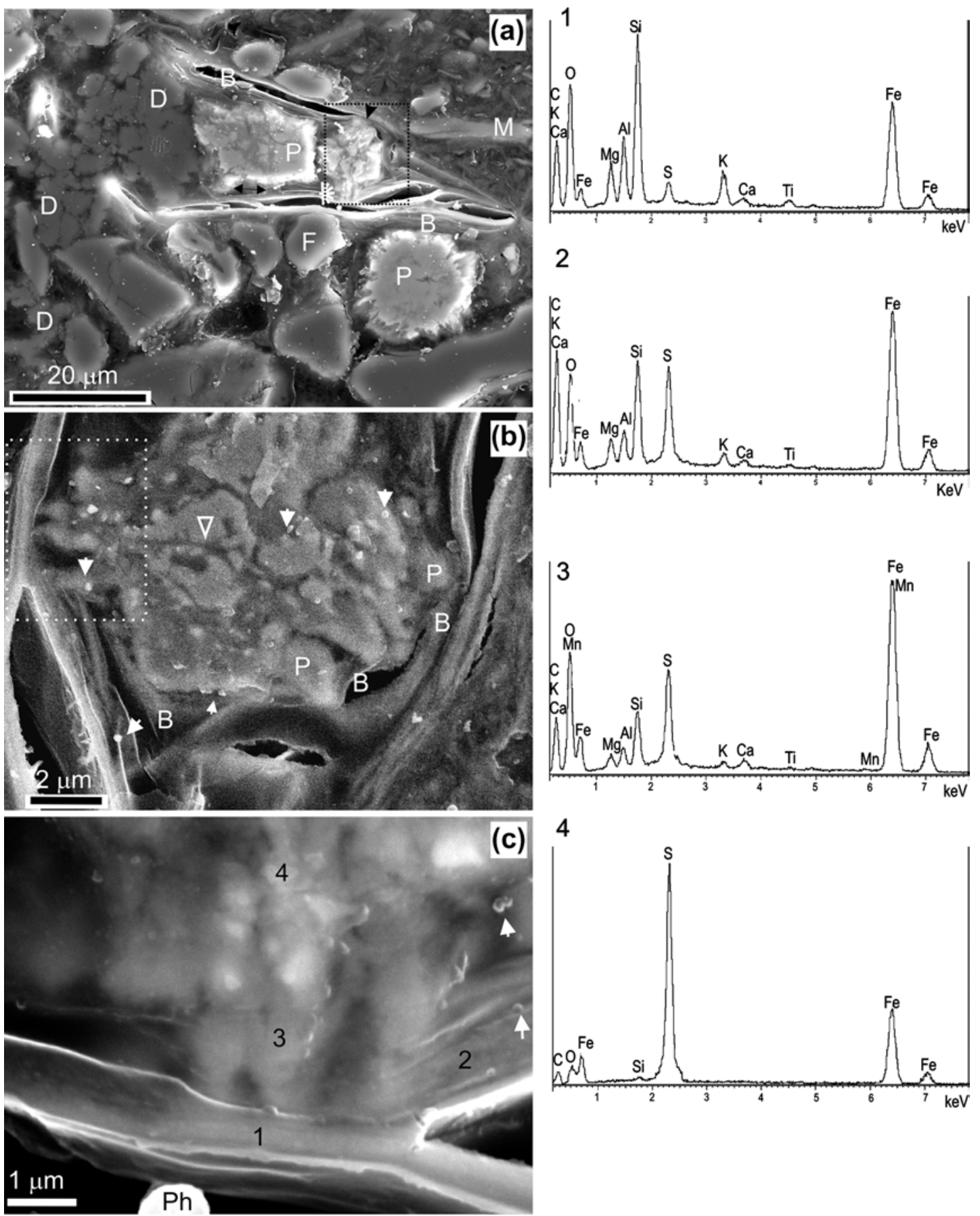

Fig. 11. (a) SEM image of pyrite (P) and dolomite (D) crystals coexisting in the inner surfaces of an exfoliated biotite (B), which rest together with other detrital silicates (some muscovite: $\mathrm{M}$ and feldspars: $\mathrm{F}$ are labelled). Arrows indicate pyrite prolongations inside the biotite. The white arrow head shows the area magnified in (c). (b) FE-SEM image showing area squared in (a) showing the asymmetric development of the alteration products (sulphides, P) as well as the irregular contact with the biotite (B). Spheroidal to oblong bodies (white arrows) are ubiquitous in the sulphide and in the interface. Hollow arrow points to a bifurcated filament-like mould. (c) SEM image across the interface between the phyllosilicate and iron sulphide products shown in (a) and squared in (b). Notice that some aspects of the parent structure of the biotite are retained in the iron sulphide. Arrows point to spheroidal bodies. A phosphate ( $\mathrm{Ph})$ concretion is attached to an inner surface of the phyllosilicate. The spectra correspond to four point analyses measured by SEM-EDS in the interface shown in (c) and denote that the alteration sequence from original biotite (1) proceeded through a sequence of intermediate products (2-3) to pyrite (4), with the gain of Fe.

and pyrite precipitates in marine sandstones from Australia. The phosphates in some cases were observed within altered mica grains. The author interpreted that phosphates formed shortly after burial from the P released into pore waters following bacterial decomposition of organic matter within the zone of sulphate reduction and methanogenesis. 

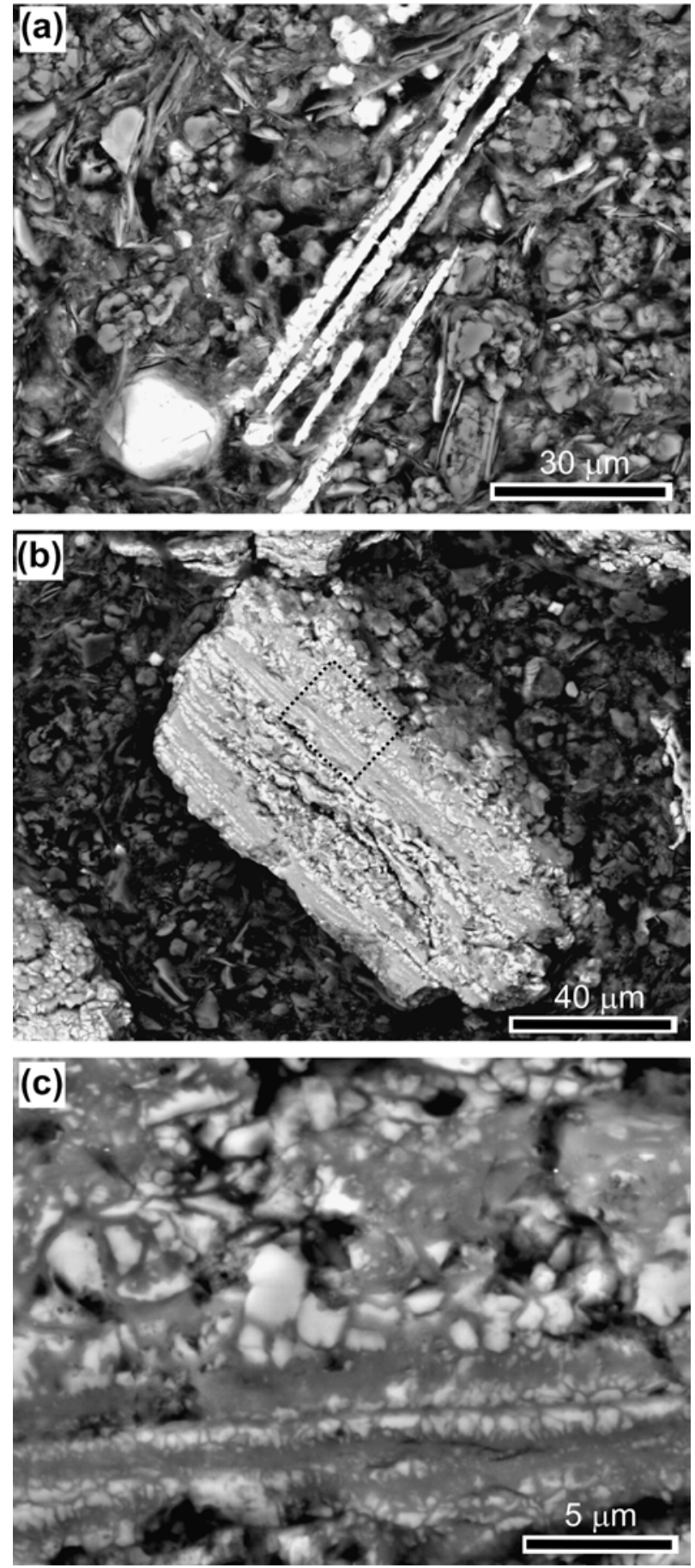

Fig. 12. SEM-BSE images. (a) Pyrite (white minerals) can occur both along the exploited planes and replacing a given phyllosilicate. (b) Biotite replacements by sulphide involve the retention of the parent mineral structure. (c) Magnified view of the squared area of (b) showing the pyrite crystallites arranged preferentially along the phyllosilicate cleavages.

\subsection{Microbial weathering of iron-bearing phyllosilicates}

Apart from the aforementioned presence of typical bioelements $(\mathrm{C}, \mathrm{S}$, and $\mathrm{P})$ and isotope signatures attributed to microbial fractionation, a number of textural features point out that the phyllosilicate dissolution was not caused by abiological processes only. Namely, the mineral alteration and/or replacement are preferentially concentrated in Febearing phyllosilicates and absent in other layered minerals located in the vicinity, which denotes specificity. The ironrich, pointed edges in pyrite crystals are only observed alongside the distorted phyllosilicates, suggesting Fe uptake inside the sheet silicates. The development of irregular patterns of alteration that are unlike patterns produced by chemical weathering (Fisk et al., 1998; Furnes et al., 2002). On the contrary, mineral replacement reactions produced primarily by dissolution and reprecipitation processes take place along sharp fronts (Putnis, 2002). Different precipitates with diverse crystallinity and chemical composition, mostly carbonates and sulphides, can coexist along the exfoliated minerals. The close coexistence of different minerals is indicative of complex microenvironmental conditions inside the phyllosilicates, likely created by microbial reactions.

All pyrite grains in this study yield features susceptible of being interpreted as microbial remains, including the presence of the organic molecules in the crystals (Fig. 9), the alveolar membranes and arrangements (Fig. 8 and 9), the pyritic moulds resembling filament-like structures (Fig. 9), and the ubiquity of the spheroidal to oblong bodies in the sulphides and in the weathered surfaces of the silicates (Fig. 9 and 11). These traits have been regarded as fossilized bacteria or microbial remnants that may have performed the precipitation of the iron sulphides (e.g. Schieber, 2002; Folk, 2005).

Iron values in biotite and chlorite associated with pyrite are significantly depleted relative to $\mathrm{Si}$ and $\mathrm{Al}$. These data along with the textural and compositional observations in the interface between the Fe-rich phyllosilicates and the iron sulphides (Fig. 11) suggest that the phyllosilicates supplied the iron incorporated in the iron sulphides. Neither compositional nor textural observations indicate that such depletion was accompanied by secondary phyllosilicate formation, as described in some cases of biotite alteration to sulphide (Li et al., 1998). Instead, the alteration sequence frequently resulted in the mimic replacement of biotite by the sulphides (Fig. 12). The interpretation that the phyllosilicates are a source of iron is compatible with the ferrous iron not being freely available in pore waters under the presence of sulphides, except at low pH (Doyle, 1968). The slow reactivity of common sheet silicates with the dissolved sulphide (Poulton et al., 2004) further supports a microbial involvement in the weathering of the Fe-bearing minerals rather than a mere implication of thermodynamically driven processes.

Accordingly, textural, compositional, and isotopic evidence suggest that the Fe forming part of the sulphides could be released from the phyllosilicates through microorganism activities. The release of $\mathrm{Fe}$ benefits the microbial consortium being used as a micronutrient, and in anaerobic systems, as a terminal electron acceptor for organic matter oxidation (Fisk et al., 1998; Roden, 2003). Experiments by Roberts (2004) and Rogers \& Bennet (2004) showed that surfaces of Fe-bearing silicates were abundantly colonized by microorganisms, and suggested that microorganisms may use organic ligands to dissolve the silicate. According 


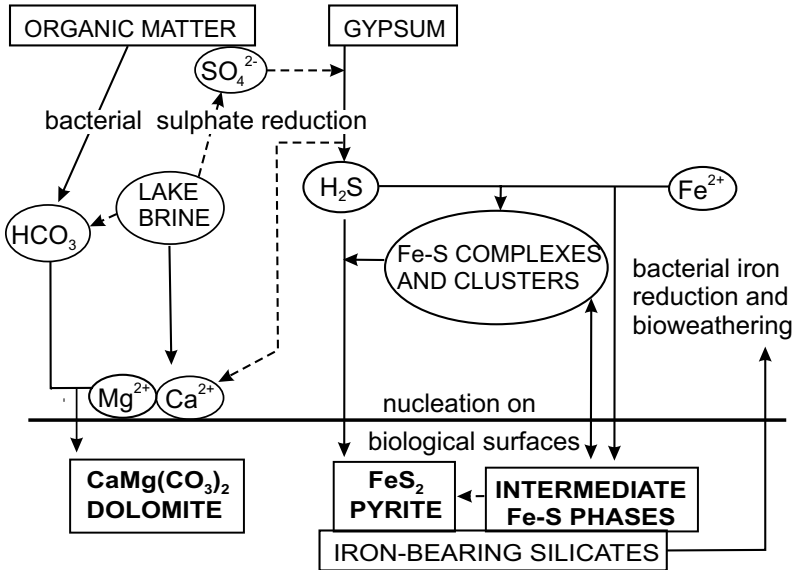

Fig. 13. Schematic model showing the interrelated pathways of sulphide and dolomite formation coupled with the weathering of Fe-rich phyllosilicates deposited in microbial mats. Sulphide and iron ions that lead to the nucleation of iron sulphides in the vicinity of altered phyllosilicates are provided by bacterial sulphate reduction and iron reduction processes, respectively. The solid phases are squared and the dissolved ones encircled, based on Pósfai \& Dunin-Borkowski (2006).

to Kostka et al. (1999) and Dong et al. (2003), the Fe (III) reducing bacteria can generate sufficient energy by reducing the ferric iron component in clays. The complex mechanisms, by which Fe (III) reducers recognize and attach to iron mineral surfaces, are detailed by Konhauser (2007).

In addition, previous X-ray photoelectron spectroscopy studies have shown that SRB-EPS has a strong affinity for iron (Beech et al., 1999) and there is evidence that iron sulphides nucleates preferentially on the cell envelopes of SRB (Rickard \& Morse, 2005; Pósfai \& Dunin-Borkowski, 2006). In modern aquatic environments the concentration of $\mathrm{Fe}$ (II) increases at the boundary between the Fe (III) and sulphate reduction zones (Berner, 1984). However, the classical sequential scheme of biogeochemical zones is an oversimplification, and now it is widely accepted that complex microbial communities exhibit uneven distribution and inhabit intricate microniches within the sediment (Konhauser, 2007). This complex ecology involves a variety of microorganisms that perform functions which will affect the iron sulphide formation, including iron-reducing organisms (Rickard \& Morse, 2005).

\subsection{Precipitation model}

Considering the isotope values, the textural data, and the composition results, including the ubiquity of organic matter with biogenic isotopic signature, and according to recent literature on the roles of bacteria in each pyrite-forming stage (i.e., Pósfai \& Dunin-Borkowski, 2006), it is suggested that the involvement of bacteria in the formation of Miocene iron sulphides was not only restricted to providing sulphide ions, but also to releasing Fe from "reactive" iron phyllosilicates and to providing nucleation sites (Fig. 13). The sulphide pseudomorphs after biotite and the pointed edges in pyrite alongside the distorted minerals indicate that the Fe uptake may have taken place directly inside the phyllosilicates and involved the formation of poorly ordered transitional $\mathrm{Fe}-\mathrm{S}$ phases (Fig. 11). This interpretation agrees with the organotemplated coprecipitation of dolomite from metabolic $\mathrm{C}$ released during bacterial sulphate reduction of organic matter (Fig. 13).

\section{Conclusions}

The early weathering of iron-bearing phyllosilicates deposited on microbial mats thriving in salt-lake environments during the Miocene of the Madrid Basin appears to have been catalysed by microbial activities. Clusters of pyrite precipitated in the weathered layers together with dolomite favoured the disaggregation and eventually the replacement of the mineral. Carbon and sulphur isotopic signatures, along with petrographic and compositional evidence, suggest that the sulphide for pyrite formation was produced by bacterial sulphate reduction and the iron was microbially released from deeply weathered Fe-rich silicates. The pyrite crystals with pointed edges enriched in iron are observed only alongside the distorted phyllosilicates, suggesting that the Fe uptake may have taken place directly inside the phyllosilicates and involved the formation of transitional mineral phases that finally replaced the mineral.

The preferential attack of Fe-rich minerals and the significant depletion of $\mathrm{Fe}$ measured in biotite and chlorite would be indicative of the interest of microorganisms for this limiting nutrient, especially in anoxic conditions, where it can be used as an electron acceptor. The coexistence of microbial carbonates with pyrite confirms the role of the sulphate reducer microbes in the formation of surface dolomite. This mineral assemblage, including weathered phyllosilicates, has a high potential for preservation, which validates its use as a biomarker.

Acknowledgements: The financial support of the research Projects PR45/05-14165 (Madrid Community) and PR34/ 07-15900 (Santander-Complutense) is gratefully acknowledged.

\section{References}

Ayllón-Quevedo, F., Souza-Egipsy, V., Sanz-Montero, M.E., Rodríguez-Aranda, J.P. (2007): Fluid inclusion analysis of twinned selenite gypsum beds from the Miocene of the Madrid basin (Spain). Implication on dolomite bioformation. Sed. Geol., 201, 212-230.

Barker, W.W. \& Banfield, J.F. (1996): Biologically versus inorganically mediated weathering reactions: relationships between minerals and extracellular microbial polymers in lithobiontic communities. Chem. Geol., 132, 55-70.

Barker, W.W., Welch, S.A., Banfield, J.F. (1997): Geomicrobiology of silicate mineral weathering. in "Geomicrobiology: interactions between microbes and minerals", J.F. Banfield \& 
K.H. Nealson, eds. Rev. Mineral., 35, Mineralogical Society of America, Washington, 391-428.

Beech, I.B., Hanjanksit, L., Kalaji, M., Neal, A., Zinkevich, V. (1999): Exopolymer production by planktonic and biofilm Pseudomonas sp. NCIMB 2021 cells in continuous culture. Microbiol., 145, 1491-1497.

Berner, R.A. (1984): Sedimentary formation of pyrite: an update. Geochim. Cosmochim. Acta, 48, 605-615.

Calvo, J.P., Alonso-Zarza, A.M., García Del Cura, M.A., Ordóñez, S., Rodríguez-Aranda, J.P., Sanz-Montero, M.E. (1996): Sedimentary evolution of lake systems through Miocene, Madrid Basin. Paleoclimatic and Paleohydrological constraints. in "Tertiary basins of Spain", P. Friend \& C. Dabrio, eds. Cambridge University Press, Cambridge, 264-269.

Chafetz, H.S. \& Guidry, S.A. (1999): Bacterial shrubs, crystal shrubs, and ray-crystal crusts: bacterially induced vs. abiotic mineral precipitation. Sed. Geol., 126, 57-74.

Dong, H., Kotska, J.E., Kim, J. (2003): Microscopic evidence for microbial dissolution of smectite. Clays Clay Minerals, 51, 502-512.

Doyle, R.W. (1968): Identification and solubility of iron sulfide in anaerobic lake sediment. Am. Jour. Sc., 2666, 980-994.

Ehrlich, H.L. (1996): How microbes influence mineral growth and dissolution. Chem. Geol., 132, 5-9.

- (1998): Geomicrobiology: its significance for geology. EarthScience Reviews, 45, 45-60.

Eugster, H.P. \& Hardie, L.A. (1978): Saline lakes. in "Physics and chemistry of lakes", A. Lerman, ed. Springer-Verlag, New York, 237-293.

Fisk, M.R., Giovannoni, S.J., Thorseth, I.H. (1998): Alteration of oceanic volcanic glass: textural evidence of microbial activity. Science, 281, 978-980.

Folk, R. (2005): Nannobacteria and the formation of framboidal pyrite: textural evidence. J. Earth System Science, 114, 369-374.

Fraiser, M.L. \& Corsetti, F.A. (2003): Neoproterozoic carbonate shrubs: interplay of microbial activity and unusual environmental conditions in post-snowball Earth oceans. Palaios, 18, 378-387.

Furnes, H., Muehlenbachs, K., Torsvik, T., Tumyr, O., Shi, L. (2002): Bio-signatures in metabasaltic glass of a Caledonian ophiolite, West Norway. Geol. Mag., 139, 601-608.

Gerdes, G., Klenke, T., Noffke, N. (2000): Microbial signatures in peritidal siliciclastic sediments: a catalogue. Sedimentology, 47, 279-308

Glenn, C.R. \& Arthur, M.A. (1988): Petrology and major element geochemistry of Peru margin phosphorites and associated diagenetic minerals: authigenesis in modern organic-rich sediments. Mar. Geol., 80, 231-267.

Grassineau, N.V. (2006): High-precision EA-IRMS analysis of S and $\mathrm{C}$ isotopes in geological materials. in "Frontiers in Analytical Geochemistry - An IGC 2004 Perspective", R. Harmon \& R. Vannucci, eds. Appl. Geochem., 21, 756-765.

Kalinowski, B.E., Liermann, L.J., Brantley, S.L., Barnes, A., Pantano, C.G. (2000): X-ray photoelectron evidence for bacteriaenhanced dissolution of hornblende. Geochim. Cosmochim. Acta, 64, 1331-1343.

Konhauser, K. (2007): Introduction to geomicrobiology. Blackwell Publishing, 425 pp.

Kostka, J.E., Wu, J., Nealson, K.H., Stucki, J.W. (1999): The impact of structural $\mathrm{Fe}(\mathrm{III})$ reduction by bacteria on the surface chemistry of clay minerals. Geochim. Cosmochim. Acta, 63, 3705-3713.

Li, G., Peacor, R., Essene, E.J. (1998): The formation of sulfides during alteration of biotite to chlorite-corrensite. Clays Clay Minerals, 46, 649-657.
Liermann, L.J., Kalinowski, B.E., Brantley, S.L., Ferry, J.G. (2000): Role of bacterial siderophores in dissolution of hornblende. Geochim. Cosmochim. Acta, 64, 587-602.

Machel, H.G. (2001): Bacterial and thermochemical sulphate reduction in diagenetic settings - old and new insights. Sed. Geol., 140, 143-175.

Ordóñez, S., Calvo, J.P., García del Cura, M.A., Alonso-Zarza, A.M., Hoyos, M. (1991): Sedimentology of sodium sulphate deposits and special clays from the Tertiary Madrid Basin (Spain). in "Lacustrine Facies Analysis", P. Anadon, L. Cabrera, K. Kelts, eds. I.A.S. Spec. Pub., 1, 39-55.

Pérez-Soba, C. (1992): Petrología y geoquímica del macizo granítico de La Pedriza, Sistema Central Español. PhD Thesis, Facultad de Geología, Universidad Complutense, Madrid, 222 pp.

Pósfai, M. \& Dunin-Borkowski, R.E. (2006): Sulfides in biosystems. Rev. in Mineral. and Geochem., 61, 679-714.

Poulton, S.W., Krom, M.D., Raiswell, R. (2004): A revised scheme for the reactivity of iron (oxyhydr) oxide minerals towards dissolved sulfide. Geochim. Cosmochim. Acta, 15, 3703-3715.

Putnis, A. (2002): Mineral replacement reactions: from macroscopic observations to microscopic mechanisms. Min. Mag., 66, 689-708.

Rasmussen, B. (1996): Early-diagenetic REE-phospate minerals (Florencite, Gorceixite, Crandallite and xenotime) in marine sandstones: a major sink for oceanic phosphorous. Amer. J. Sci., 296, 601-632.

Rickard, D. \& Morse, J.W. (2005): Acid volatile sulfide (AVS). Mar. Chem., 97, 141-197.

Roberts, J.A. (2004): Inhibition and enhancement of microbial surface colonization: the role of silicate composition. Chem. Geol., 212, 313-327.

Roden, E.E. (2003): Fe(III) oxide reactivity toward biological versus chemical reduction. Environ. Sci. and Technology, 37, 1319-1324.

Rodríguez-Aranda, J.P., Rouchy, J.M., Calvo, J.P., Ordóñez, S., García del Cura, M.A. (1995): Unusual twinning features in large primary gypsum crystals formed in salt lake conditions, Middle Miocene, Madrid Basin, Spain - palaeoenvironmental implications. Sed. Geol., 95, 123-132.

Rodríguez-Aranda, J.P., Calvo, J.P., Sanz-Montero, M.E. (2002): Lower Miocene gypsum palaeokarst in the Madrid Basin (central Spain): dissolution, diagenesis, morphological relics and karst end-products. Sedimentology, 49, 1385-1400.

Rogers, J.R. \& Bennet, P.C. (2004): Mineral simulation of subsurface microorganisms: release of limiting nutrients from silicates. Chem. Geol., 203, 91-108.

Rogers, J.R., Bennet, P.C., Choi, W.J. (1998): Feldspar as a source of nutrients for microorganisms. Am. Mineral., 83, 1532-1540.

Sanz-Montero, M.E., Rodríguez-Aranda, J.P., García del Cura, M.A. (2008): Dolomite-silica stromatolites in Miocene lacustrine deposits from the Duero Basin, Spain: the role of organotemplates in the precipitation of dolomite. Sedimentology, 55, 729-750.

Sanz-Montero, M.E., Rodríguez-Aranda, J.P., Calvo, J.P. (2006): Mediation of endoevaporitic microbial communities in early replacement of gypsum by dolomite: a case study from Miocene lake deposits of the Madrid Basin, Spain. J. Sediment. Res., 76, 1257-1266.

Schieber, J. (1999): Microbial mats in terrigenous clastics: the challenge of identification in the rock record. Palaios, 14, 3-12.

- (2002): Sedimentary pyrite: a window into the microbial pasts. Geology, 30, 531-534.

Trudinger, P.A., Chambers, L.A., Smith, J.W. (1985): Low-temperature sulphate reduction: biological versus abiological. Can. J. Earth Sci., 22, 1910-1918. 
Ullman, W.J., Kirchman, D.L., Welch, S.A., Vandevivere, P. (1996): Laboratory evidence for microbially mediated silicate mineral dissolution in nature. Chem. Geol., 132, 11-17.

Vasconcelos, C. \& McKenzie, J.A. (1997): Microbial mediation of modern dolomite precipitation and diagenesis under anoxic conditions (Lagoa Vermelha, Rio de Janeiro, Brazil). J. Sediment. Res., 67, 378-390.

Vasconcelos, C., Warthmann, R., McKenzie, J.A., Visscher, P.T., Bittermann, A.G., van Lith, Y. (2006): Lithifying microbial mats in Lagoa Vermelha, Brazil: modern precambrian relics? Sed. Geol., 185, 175-183.

Villaseca, C. \& Barbero, L. (1994): Chemical variability of Al-Fe$\mathrm{Ti}-\mathrm{Mg}$ minerals in peraluminous granitoid rocks from Central Spain. Eur. J. Mineral., 6, 691-710.

Villaseca, C. \& Ubanell, A.G. (2005): El macizo metagranítico de la Cebollera (Pico de las Tres Provincias, Somosierra, Sistema Central español): Nuevos datos sobre el metamorfismo hercínico del sector de Somosierra. Rev. Soc. Geol. Esp., 18, 115-131.

Welch, S.A., Barker, W.W., Banfield, J.F. (1999): Microbial extracellular polysaccharides and plagioclase dissolution. Geochim. Cosmochim. Acta, 63, 1405-1419.
Wilson, M.J. (2004): Weathering of rock-forming minerals. Clay Minerals, 39, 233-266.

Wright, D.T. (1999): The role of sulphate-reducing bacteria and cyanobacteria in dolomite formation in distal ephemeral lakes of Coorong region, South Australia. Sed. Geol., 126, 147-157.

Wright, D.T. \& Wacey, D. (2005): Precipitation of dolomite using sulphate-reducing bacteria from the Coorong Region, South Australia: significance and applications. Sedimentology, 52, 987-1008.

Zhang, G., Dong, H., King, J., Eberl, D.D. (2007): Microbial reduction of structural $\mathrm{Fe}^{3+}$ in nontronite by a thermophilic bacterium and its role in promoting the smectite to illite reaction. Am. Mineral., 92, 1411-1419.

Received 11 February 2008

Modified version received 13 May 2008

Accepted 23 July 2008 